Э. Н. Елаев и др. История гнездования и динамика численности большого баклана (Phalacrocorax carbo L., 1758) в Байкальской Сибири

Научная статья

УДК 591.526(571.54)

DOI $10.18101 / 2587-7143-2021-3-21-32$

\title{
ИСТОРИЯ ГНЕЗДОВАНИЯ И ДИНАМИКА ЧИСЛЕННОСТИ БОЛЬШОГО БАКЛАНА (Phalacrocorax carbo L., 1758) В БАЙКАЛЬСКОЙ СИБИРИ
}

(C) Елаев Эрдэни Николаевич

доктор биологических наук, профессор, Бурятский государственный университет имени Доржи Банзарова Россия, 670000, г. Улан-Удэ, ул. Смолина, 24a elaev967@yandex.ru

\section{(C) Доржиев Цыдыпжап Заятуевич} доктор биологических наук, профессор, Бурятский государственный университет имени Доржи Банзарова Россия, 670000, г. Улан-Удэ, ул. Смолина, 24а; главный научный сотрудник, Институт общей и экспериментальной биологии СО РАН Россия, 670047, г. Улан-Удэ, ул. Сахьяновой, 6 tsydypdor@mail.ru

\section{(C) Ананин Александр Афанасьевич} доктор биологических наук, заместитель директора по НИР, Заповедное Подлеморье, Россия, Республика Бурятия, 671623, пос. Усть-Баргузин, ул. Ленина, 71 главный научный сотрудник, Институт общей и экспериментальной биологии СО РАН Россия, 670047, г. Улан-Удэ, ул. Сахьяновой, 6 a_ananin@mail.ru

(C) Пыжьянов Сергей Владимирович доктор биологических наук, профессор, Иркутский государственный университет Россия, 664011, г. Иркутск, ул. Нижняя Набережная, 8 pyzh@list.ru

\section{(C) Янкус Геннадий Андреевич}

научный сотрудник, Заповедное Подлеморье, Россия, Республика Бурятия, 671623, пос. Усть-Баргузин, ул. Ленина, 71 jankus@rambler.ru

\section{(C) Бадмаева Евгения Николаевна}

кандидат биологических наук, доцент, Бурятский государственный университет имени Доржи Банзарова Россия, 670000, г. Улан-Удэ, ул. Смолина, 24a jessi@inbox.ru 


\title{
(C) Мокридина Мария Сергеевна
}

кандидат биологических наук, старший преподаватель Иркутский государственный университет

Россия, 664011, г. Иркутск, ул. Нижняя Набережная, 8 rjs-92@mail.ru

\author{
(C) Аюрзанаева Ирина Андреевна \\ магистрант, \\ Бурятский государственный университет им. Д. Банзарова \\ Россия, 670000, г. Улан-Удэ, ул. Смолина, 24a, \\ научный сотрудник, Заповедное Подлеморье, \\ Россия, Республика Бурятия, 671623, пос. Усть-Баргузин, ул. Ленина, 71 \\ aurzanaeva@gmail.com
}

\begin{abstract}
Аннотация. В статье описана история пребывания и современное распространение большого баклана (Phalacrocorax carbo L., 1758) в Байкальской Сибири в результате вторичной экспансии в первой четверти XXI века. Основными местами работ стали дельта p. Селенги, пролив Малое Море, о-ва Чивыркуйского залива, ВерхнеАнгарский сор на Байкале; Верхне-Ангарская и Баргузинская котловины, оз. Гусиное в Прибайкалье и Забайкалье, где когда-то, по известным литературным источникам, с XVII в. до середины XX в. обитал этот вид. Прослежена динамика численности баклана в разных районах на основе прямого учета птиц в гнездовых колониях, а также неразмножающихся птиц, что позволило оценить общую численность бакланов в 2021 г. на Байкале и стабилизации численности в соответствии с экологической емкостью среды. Рассмотрен ареал большого баклана с подвидами, определены гидрологические изменения мест его обитания.
\end{abstract}

Ключевые слова: большой баклан, распространение, гнездование, Байкальская Сибирь.

Благодарность. Работа выполнена в рамках государственного контракта № 00061 «Проведение научно-исследовательских работ, направленных на формирование сведений, обосновывающих целесообразность регулирования численности объектов животного мира (большой баклан) на территории Республики Бурятия» и при частичной финансовой поддержке гранта инновационных научных исследований Бурятского государственного университета в 2021 г. (№ 21-06-0502).

\section{Для цитирования}

История гнездования и динамика численности большого баклана (Phalacrocorax carbo L., 1758) в Байкальской Сибири / Э. Н. Елаев, Ц. 3. Доржиев, А. А. Ананин [и др.] // Вестник Бурятского государственного университета. Биология. География. 2021. № 3. С. 21-32.

Введение. В настоящее время на большей территории Байкальской Сибири ${ }^{1}$ большой баклан (Ph. carbo) - это перелетный гнездящийся вид, восстановивший буквально за последние 20 лет свой былой ареал в российской части бассейна оз. Байкал. В первых изданиях красных книг Байкальского региона ${ }^{1}$ (Ир-

\footnotetext{
${ }^{1}$ Под Байкальской Сибирью (Байкальский регион) понимается водосборный бассейн озера Байкал как трансграничная территория между Российской Федерацией и Монголией, при этом в пределах российской части - это собственно озеро Байкал и субъекты Российской Федерации: Республика Бурятия (73\% общей территории), Забайкальский край $(21 \%)$ и Иркутская область (6\%).
} 
Э. Н. Елаев и др. История гнездования и динамика численности большого баклана (Phalacrocorax carbo L., 1758) в Байкальской Сибири

кутская область, Республика Бурятия и Забайкальский край) он относился к исчезнувшим (Красная книга .., 1988, 2005) или редким (Красная книга ..., 2000) видам. А в последующих был либо отнесен к восстановившимся (V категория) (Красная книга ..., 2010), либо вообще исключен из списка «краснокнижных» (Красная книга ..,, 2012; Красная книга ..., 2013; Красная книга ..., 2020). В монгольской части ситуация была и остается относительно стабильной: гнездование отмечено на водоемах Главного Хангайского хребта (междуречье Тамира и Орхона, оз. Угий), хребтов Тарбагатай и Болнай (озера Тэлмэн, Сангийн-Далай, Тэрхийн-Цагаан), в Дархатской котловине (долина р. Шишгэд, оз. Доод-Цагаан), на оз. Хубсугул, водоемах в среднегорьях бассейна Селенги и Орхона (Звонов и др., 2016).

В связи с этим исходя из вопроса истории пребывания этого вида в регионе и проблемы сохранения биоразнообразия Байкальской Сибири встает вопрос об организации мониторинга численности восстановившегося вида и вероятностного его регулирования.

Результаты, обсуждение и заключение. История байкальской популяции баклана достаточно драматична. Во второй половине двадцатого столетия вид был широко распространен по Восточной Сибири, в особенности на оз. Байкал - одном из крупных внутренних водоемов на юге Восточной Сибири. Так, Густав Радде, путешествуя по Байкалу в 1857 г., отмечал тысячные стаи на Байкале, в дельтах р. Баргузин и Селенга (Radde, 1863), такую же картину описывали Б. (И.) Дыбовский и В. (А.) Годлевский. Однако уже в конце XIX - начале XX в. его численность начала снижаться, а в начале 1970-х гг. он исчез на Байкале и отмечались только редкие залеты этих птиц (Литвинов, 1982; Егоров и др., 1984; Доржиев и др., 1985; Доржиев и др., 1986; Васильченко, Прокопьев, 1988; Попов, 1993; Пыжьянов и др., 1997; Ешеев, Елаев, 2005). Последняя бакланья колония была обнаружена в конце 1957 г. О. К. Гусевым (1960), а летом 1969 г. птиц здесь уже не было; последнее гнездо в Чивыркуйском заливе было обнаружено в 1967 г. (Гусев, 1980; Васильченко, Прокопьев, 1988), на западном берегу озера, в частности на мысе Кобылья Голова и в окрестностях пос. Ташкай, соответственно в 1962 г. и 1964 г. (Попов, 1993). После этого, несмотря на достаточно интенсивные орнитологические исследования, до начала XXI века на Байкале отмечались только редкие залетные птицы (Пыжьянов и др., 1997).

Исчезновение бакланов произошло так стремительно, что биология и экология этого вида на Байкале остались практически неизученными, есть только отрывочные сведения о сроках прилета, характере гнездостроительства и приблизительной численности. В силу высокой численности и обычности баклана никто «не торопился» с изучением его экологии и подсчетом численности (Пьжьянов и др., 2016). Судя по всему, он был одним из фоновых видов на побережье Байкала, о чем свидетельствуют многочисленные сохранившиеся географические названия (мысы, острова: мыс Бакланий, Большой (Малый) Бакланий Камешек и т. д.).

В Юго-Западном Забайкалье единственная колония больших бакланов, которая просуществовала до 40-х годов XX в., располагалась в смешанном лесу на северо-западном берегу Гусиного озера в устье р. Ахур (Измайлов, Боровицкая, 1973; А. А. Московский, устное сообщение). Все чучела и тушки этого вида, имеющиеся в Кяхтинском краеведческом музее им. акад. В. А. Обручева, отно- 
сятся к началу XIX в. и добыты на Байкале, Гусином озере, по р. Чикой (Доржиев и др., 1990).

Начиная с конца 70-х гг. XX в. бакланы вновь начали появляться на Байкале и в Забайкалье. Так, летом 1977 г. В. Г. Егоров (1980) встретил одну особь на оз. Малый Арангатуй. С 1979 по 1986 г. бакланов в колониях серебристых чаек ежегодно наблюдал на островах Малого Моря С. В. Пыжьянов (Пыжьянов и др., 1998), в начале июня 1979 г. — на юге Байкала В. Развозжаев, 14/V 1984 г. — в устье р. Голоустная (Богородский, 1989). В 1983 г. встреч было особенно много (С. В. Пыжьянов, устное сообщение; цит. по: В. В. Попов, 1993). Залетные бакланы встречались также на турбазе «Прибой» в 1972 г. (Шкатулова, 1980), в дельте р. Селенги с 1979 по 1994 г., на северном Байкале в 1982, 1987, 1991 гг. (Пыжьянов и др., 1997), на мысе Мужинай в 1979 г., на мысе Крестовый в 1985 г., в бухте Покойная в 1994 г. (Попов, 1993; Попов и др., 1998). Мы видели залетных птиц на оз. Арангатуй в начале июня 1995 г., в окрестностях с. Киран (Кяхтинский р-н) 2/V 1998 г. (Доржиев и др., 1998).

Таким образом, с конца 70-х - начала 80-х гг. до конца 90-х прошлого столетия бакланы с разной частотой стали встречаться в Байкальской Сибири. Одиночные птицы и небольшие стайки отмечены в разных районах Байкала и в Южном Забайкалье (Попов, 1993; Пыжьянов и др., 1997; Доржиев и др., 1998; Фефелов и др., 2001). Единственным местом гнездования бакланов на юге Восточной Сибири и Северной Монголии в то время были озера Торейской котловины в Юго-Восточном Забайкалье и оз. Хубсугул (Зубакин, 1981; Васильченко, 1989; Сумъяа, Скрябин, 1989; Болд и др., 1991; Елаев и др., 2000; Ткаченко, Пузанский, 2000).

В настоящее время численность большого баклана на Байкале восстанавливается, и быстрые темпы естественной реинтродукции данного вида обусловлены массовым переселением его из других регионов (Пыжьянов и др., 2010; Пыжьянова, 2016; Пыжьянов, Пыжьянова, Тупицын, 2016; Фефелов и др., 2016; Ананин и др., 2016; 2018а; 2018б; Овдин и др., 2017; 2018 и др.). Заселение островов и мысов Байкала идет столь стремительно, что ситуация меняется ежегодно, начиная с 2006/08 гг. до н. в. (рис. 1).

Так, по учетам 2006-2007 гг. (Пыжьянов и др., 2016) численность гнездовий баклана на острове Хубын составила 26, а в 2015 г. - 450-500 гнезд; на острове Едор в 2007 г. - 15, а в 2015 г. - уже 180 гнезд. Постепенно заселились и другие острова: Изохой - 155 гнезд баклана (2015 г.); Угунгой (522 и 116 гнезд). Баклан заселил и мысы острова Ольхон, где его численность на сегодня составляет примерно 300 гнезд. В 2021 г. у острова Ольхон в районе Малого моря отмечено 21 поселение большого баклана (количество гнезд в колонии в среднем 85; Lim 10-230), в котором по самым общим учетам насчитывалось 1700-1800 жилых гнезд. В целом на островах Малого моря после естественной вспышки в начале вторичной экспансии численность птиц в этом районе оз. Байкал стабилизировалась, что свидетельствует о «встраивании» вида в экосистему озера и его численность приходит в соответствие с экологической емкостью среды (рис. 2). 
Э. Н. Елаев и др. История гнездования и динамика численности большого баклана (Phalacrocorax carbo L., 1758) в Байкальской Сибири

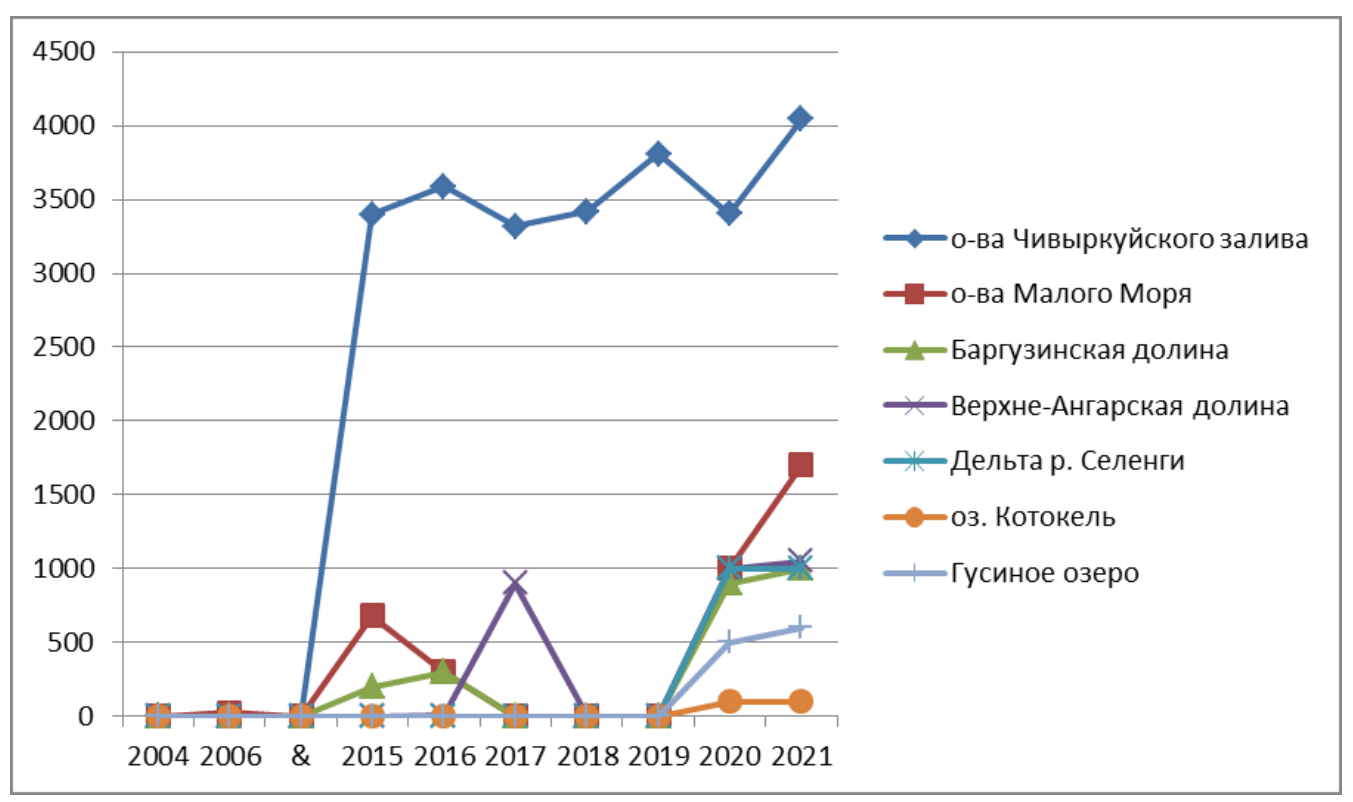

Рис. 1. Суммарная динамика численности гнездящихся бакланов на оз. Байкал и в Забайкалье в пределах Республики Бурятия в первой четверти XXI века

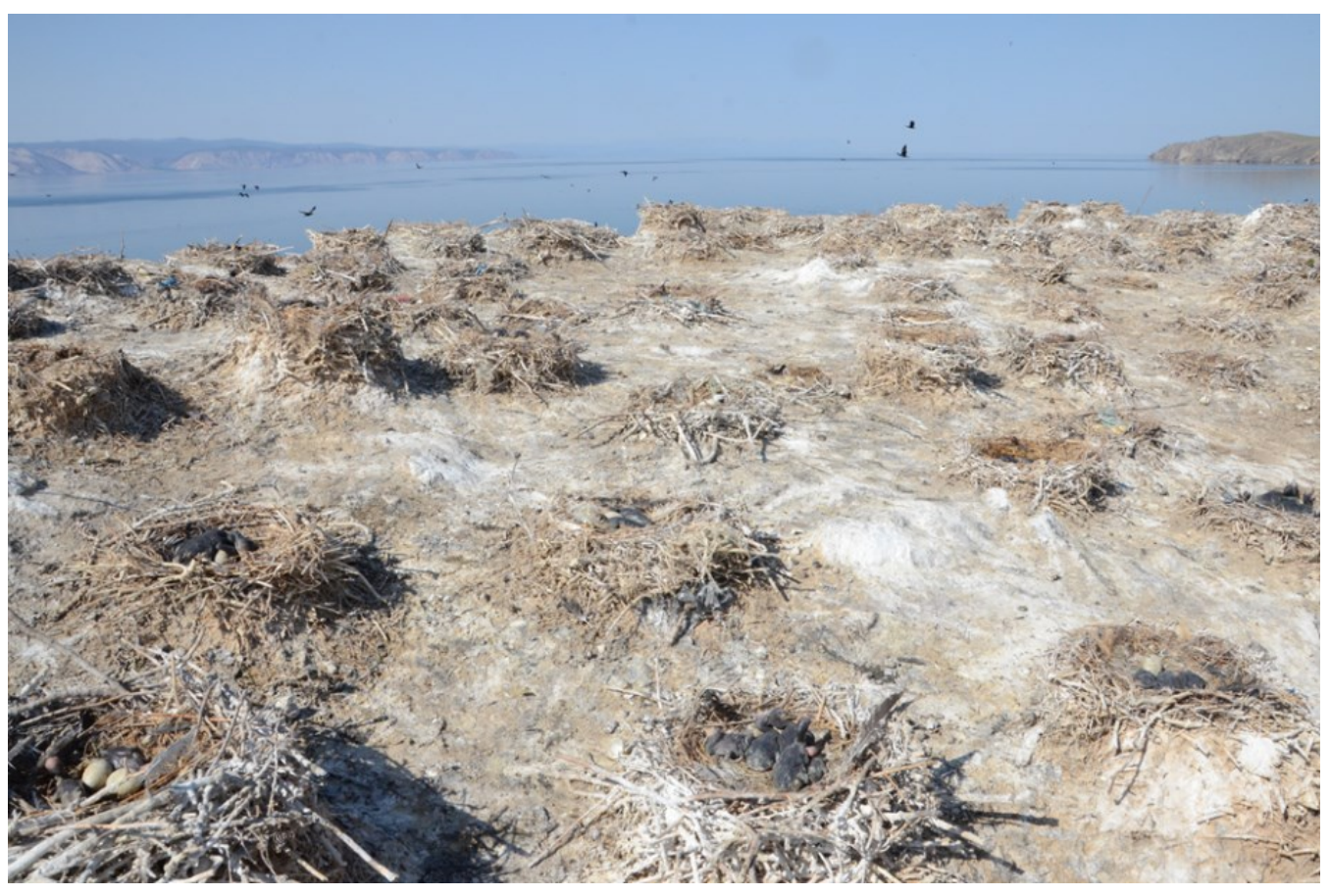

Рис. 2. Гнездовые колонии большого баклана «маломорской» популяции (автор фото С. В. Пыжьянов; май-июнь 2021 г.) 
В Чивыркуйском заливе численность гнездящихся птиц в 2015-2017 гг. стабилизировалась на уровне 3200-3500 пар. Негнездящаяся часть группировки (молодые неполовозрелые птицы и взрослые особи, по разным причинам не приступившие к гнездованию) составила не менее 2000-3000 особей (Ананин и др., 2018a; 2018б; Овдин и др., 2017). На многочисленных протоках и озерах в долине p. Верхняя Ангара насчитывается около 10 мест коллективных ночевок с численностью от 150 до 500 особей. Летом 2017 г. верхнеангарская группировка большого баклана насчитывала не менее 5000 особей (Овдин и др., 2017), в 2021 г. численность вида осталась примерно на том же уровне (статья Г. А. Янкуса в этом номере) (рис. 3).
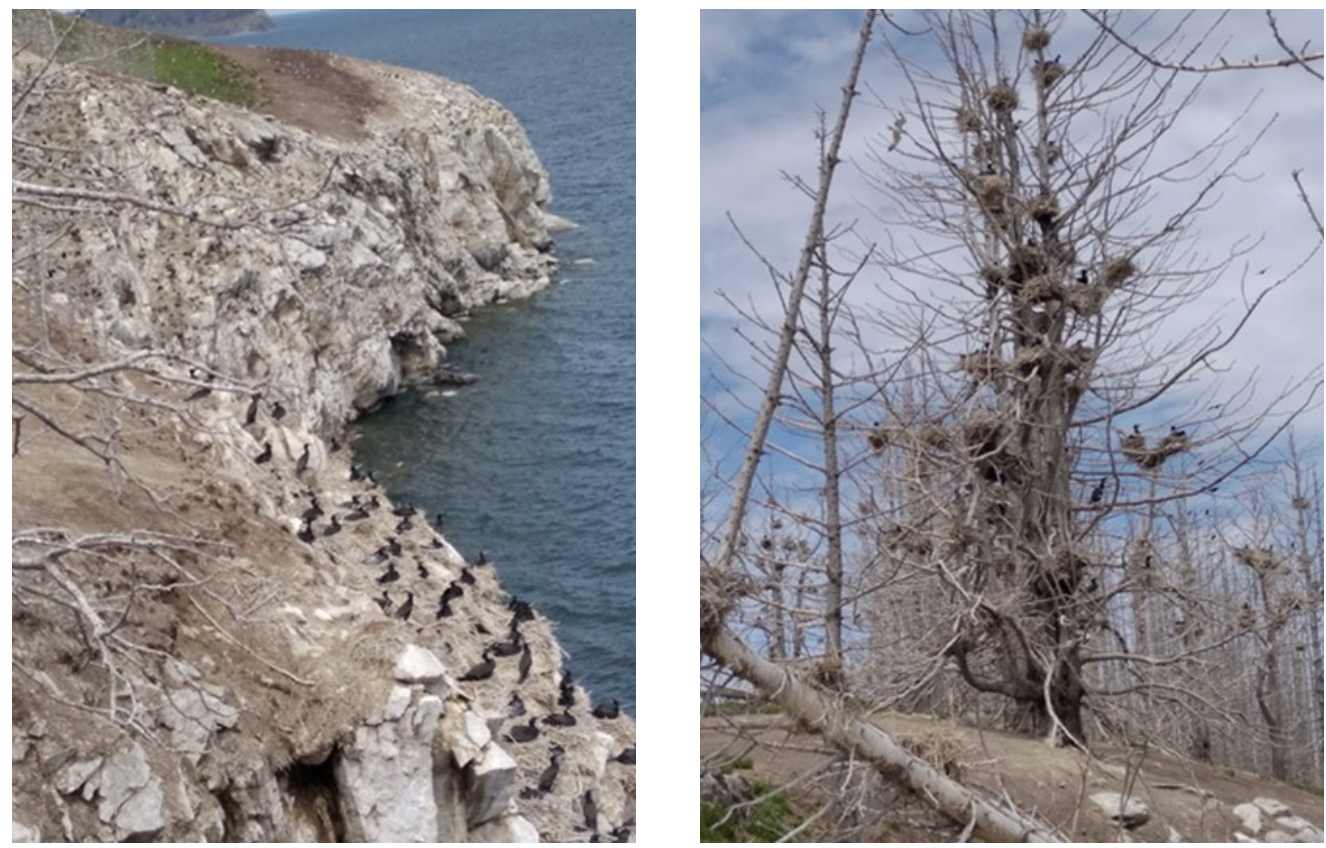

Рис. 3. Колонии больших бакланов в Чивыркуйском заливе оз. Байкал (о-в Голый; фото Э. Н. Елаева; 10-е числа июня 2021 г.)

В долине р. Баргузин больших бакланов начали встречать с 2008 г. В 2013 г. на низких закочкаренных островах средней части долины р. Баргузин были отмечены первые гнездовые колонии вида, располагавшиеся на земле. Бакланы вдоль русла р. Баргузин встречаются и на пойменных протоках и озерах. По сведениям Бурприроднадзора и опросным данным в 2015-2016 гг., в долине р. Баргузин численность вида достигала 3000-3700 особей, имелись гнездовые колонии на протоках в средней части Баргузинской долины, включающие до 200-300 гнезд. Колонии сосредоточены на р. Борогол, Ина, Баргузин, Быстрая и Аргада. В весеннее-осенний период основные места концентрации ночевок бакланов расположены на озерах Нижнего Куйтуна: оз. Саган-Нур, Барагханские и Харамодунские озера. С 2012 г. баклан начал встречаться в верховьях р. Баргузин в районах озер Балан-Тамур, Чурикто, Якондыкон группами по 10-20 особей, но колонии не отмечены (Овдин и др., 2017; Цыр. 3. Доржиев, устное сообщение). 
Э. Н. Елаев и др. История гнездования и динамика численности большого баклана (Phalacrocorax carbo L., 1758) в Байкальской Сибири

На Гусином озере в Юго-Западном Забайкалье, где когда-то обитал баклан, в лиственничнике северо-западного берега озера недалеко от бывшей колонии в устье р. Ахур была обнаружена смешанная колония, состоящая примерно из 250300 гнезд баклана и около 50 серых цапель (Ardea cinerea).

Таким образом, большой баклан не только вновь начал гнездиться на Байкале и в его бассейне, но и, как это обычно происходит на начальных этапах экспансии (тем более вторичной), увеличил свою численность практически повсеместно в российской части бассейна Байкала. На этом фоне (как пример), на оз. Хубсугул в Монголии, поскольку была и остается стабильной кормовая база (а это в основном соровая рыба), вид не исчез и здесь его численность остается относительно стабильной.

Рассматривая ареал вида с разными подвидами (рис. 4), с дополнениями Л. С. Степаняна (2003), Е. А. Коблика с соавторами (2006), можно заключить следующее с вытекающими из этого обобщениями.

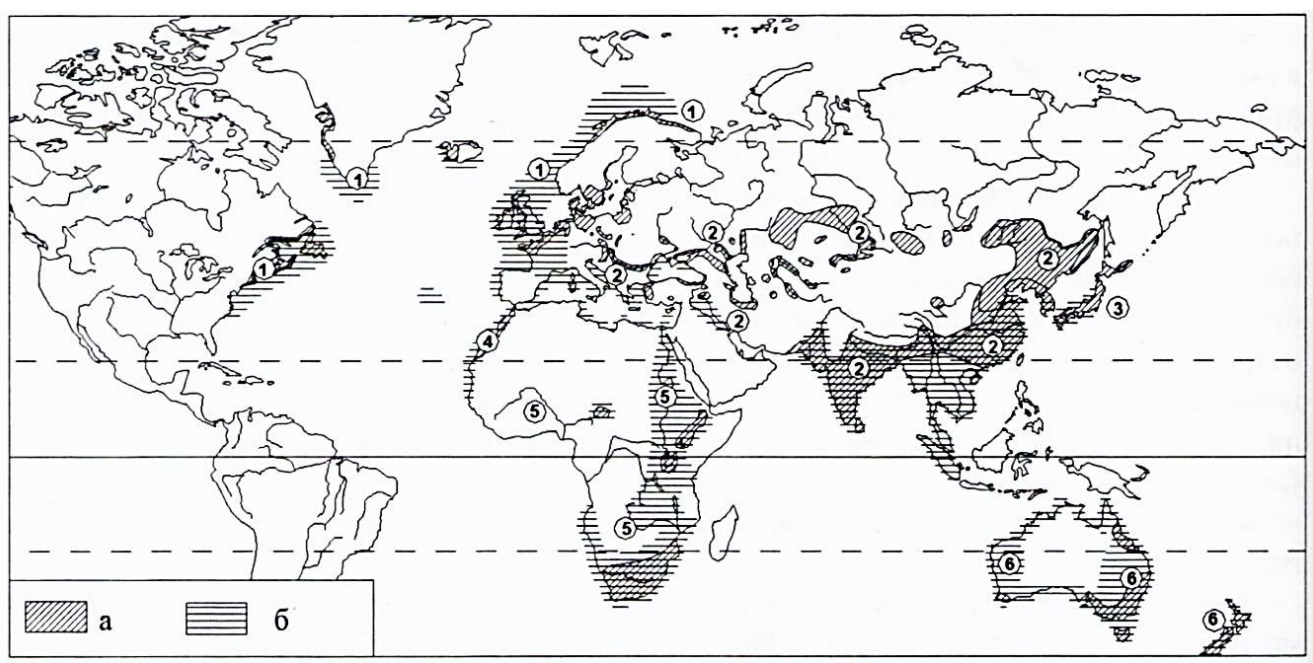

Рис. 4. Область распространения большого баклана: а - область гнездования; б - область зимовок. Подвиды: 1 - Phalacrocorax c. carbo; 2 - Ph. c. sinensis; 3 - Ph. c. hanedae; 4 - Ph. c. maroccanus; 5 - Ph. c. lucidus; 6 - Ph. c. novaehollandiae (uит.: Луговой А. Е., 2011. С. 56)

Обитающий в пределах Центральной Азии подвид Ph. c. sinensis на северной границе своего ареала подвержен разного рода инвазиям (периодическим, либо непериодическим), колебаниям численности, как и любой другой периферийный вид (Доржиев, 1997; Елаев, 2005). Изменившиеся в силу естественных исторических (цикличных) процессов (в отношении баклана «влажность - засуха», равно как лес - степь), а также обитание на границе ареала, включая экотонные (переходные) территории (Иметхенов, 1997; Yelayev, 2016), «вынуждает» вид осваивать новые территории. Поскольку в конце XX в., учитывая эти природные процессы, ближайшие к Байкальской Сибири места обитания бакланов, а именно оз. Хубсугул (Монголия) и Торейские озера на юге Забайкальского края (Россия), подверглись разного рода гидрологическим изменениям, вид «нашел» и хоро- 
шую кормовую базу, и удобные (бывшие) места гнездования, заняв тем самым собственную (некогда потерянную) экологическую нишу.

\section{Литература}

1. Гусев О. К. О гнездовании птиц на островах Чивыркуйского залива Байкала и оз. Арангатуй // Тр. Вост.-Сиб. фил. АН СССР. Благовещенск, 1960. Вып. 23. С. 35-42. Текст: непосредственный.

2. Гусев О. К. Большой баклан на Байкале // Охота и охотничье хозяйство. 1980. № 3-4. С. 14-17. Текст: непосредственный.

3. Структура населения околоводных птиц озера Хубсугул / В. А. Подковыров [и др.] // Россия и Монголия в многополярном мире: итоги и перспективы сотрудничества на рубеже тысячелетий: тез. докл. Иркутск, 2000. С. 49-50. Текст: непосредственный.

4. Ананин А. А., Овдин М. Е., Разуваев А. Е. Популяционная динамика большого баклана Phalacrocorax carbo в Забайкальском национальном парке (Чивыркуйский залив, Средний Байкал) // Русский орнитологический журнал. 2018 б. Т. 27. № 1584. С. 13901392. Текст: непосредственный.

5. Ананин А. А., Овдин М. Е., Янкус Г. А. Динамика численности большого баклана на Северном Байкале // Современные проблемы орнитологии Сибири и Центральной Азии: материалы VI Международной орнитологической конференции / ответственный редактор В. В. Попов. 2018а. С. 17-21. Текст: непосредственный.

6. Ананин А. А., Разуваев А. Е. Особенности популяционной динамики большого баклана (Phalacrocorax carbo L.) на северо-восточном побережье оз. Байкал // Разнообразие почв и биоты Северной и Центральной Азии: материалы III Всероссийской научной конференции. 2016. С. 27-31. Текст: непосредственный.

7. Васильченко А. А., Прокопьев В. Н. Большой баклан // Красная книга Бурятской АССР. Улан-Удэ: Бурят. кн. изд-во, 1988. С. 63-65. Текст: непосредственный.

8. Гагина Т. Н. Птицы Восточной Сибири (Список и распространение) // Тр. Баргузинского государственного заповедника. Москва: Типография Издательства восточной литературы, 1961. Вып. 3. С. 99-123. Текст: непосредственный.

9. Горошко О. А., Ткаченко У. Э. Реликтовая чайка // Красная Книга Забайкальского края. Животные. Новосибирск, 2012. С. 144-145. Текст: непосредственный.

10. Гусев О. К. К орнитофауне Ушканьих островов // Орнитология. 1960. Вып. 3. С. 226-233. Текст: непосредственный.

11. Гусев О. К. Большой баклан на Байкале // Охота и охотничье хозяйство. 1980. № 3. С. 14-17. № 4. С. 14-16. Текст: непосредственный.

12. Гусев О. К. О гнездовании птиц на островах Чивыркуйского залива Байкала и оз. Арангатуя // Труды Вост.-Сиб. филиала АН СССР. Благовещенск, 1960. Вып. 23; Зоология. С. 35-42. Текст: непосредственный.

13. Каталог коллекций птиц Кяхтинского краеведческого музея / Ц. 3. Доржиев, Б. О. Юмов, Л. Н. Калинина [и др.]. Улан-Удэ, 1990. 72 с. Текст: непосредственный.

14. Они нуждаются в охране: о редких и исчезающих видах фауны и флоры в Бурятии / Ц. З. Доржиев, Г. М. Хабаева, К. М. Богданова [и др.]. Улан-Удэ: Бурят. кн. изд-во, 1985. 192 с. Текст: непосредственный.

15. Дыбовский Б., Годлевский В. Предварительный отчет о фаунистических исследованиях на Байкале // Отчет о действиях Сиб. отд. Имп. Рос. геогр. о-ва за 1869 г. (Приложение). Санкт-Петербург, 1870. С. 167-204. Текст: непосредственный.

16. Егоров В. Г. О состоянии водных и околоводных птиц Чивыркуйского залива (Байкал) // Экология и охрана птиц и млекопитающих Забайкалья. Улан-Удэ: Изд-во БФ СО АН СССР. 1980. С. 31-37. Текст: непосредственный. 
Э. Н. Елаев и др. История гнездования и динамика численности большого баклана (Phalacrocorax carbo L., 1758) в Байкальской Сибири

17. Егоров В. Г., Прокопьев В. Н., Некрасов А. В. О состоянии и мерах восстановления популяций водоплавающих птиц озера Байкал // Современное состояние ресурсов водоплавающих птиц: тезисы всесоюзного семинара (20-23 окт. 1984 г.). Москва, 1984. С. 187-188. Текст: непосредственный.

18. Ермолаева Э. А., Пыжьянова М. С. Питание большого баклана на водоемах Центральной Азии // Социально-экологические проблемы Байкальского региона и сопредельных территорий: тезисы докладов международной научно-практической конференции студентов, аспирантов и молодых ученых, посвященной 100-летию Иркутского государственного университета. 2018. С. 24-26. Текст: непосредственный.

19. Звонов Б. М., Букреев С. А., Болдбаатар Ш. Птицы Монголии. Ч. І. Неворобьиные (Non-Passeriformes). Москва, 2016. 396 с. Текст: непосредственный.

20. Измайлов И. В., Боровицкая Г. К. Птицы Юго-Западного Забайкалья. Владимир: Изд-во Владимирского ин-та, 1973. 315 с. Текст: непосредственный.

21. Макаркин Е. М. Кормовое поведение большого баклана на Малом море (озеро Байкал) // Морские исследования и рациональное природопользование: материалы молодежной научной конференции. 2018. С. 233-237. Текст: непосредственный.

22. Овдин М. Е., Янкус Г. А., Ананин А. А. Большой баклан Phalacrocorax carbo на Ceверном Байкале // Байкальский зоологический журнал. 2017. № 2 (21). С. 75-79. Текст: непосредственный.

23. Овдин М. Е., Янкус Г. А., Ананин А. А. Северобайкальская и баргузинская группировки большого баклана Phalacrocorax carbo в 2017 г. на Байкале // Байкальский зоологический журнал. 2018. № 2(23). С. 57-60. Текст: непосредственный.

24. Пыжьянов С. В., Тупицын И. И., Сафронов Н. Н. Новое в авифауне Байкальского побережья // Тр. Байкало-Ленского гос. природного заповедника. 1998. Вып. 1. С. 99-102. Текст: непосредственный.

25. Пыжьянов С. В., Пыжьянова М. С. Современное состояние большого баклана на Байкале и Хубсугуле (Монголия) // Известия Иркутского государственного университета. Серия: Биология. Экология. 2010. Т. 3. № 1. С. 60-63. Текст: непосредственный.

26. Пыжьянов С. В., Пыжьянова М. С., Тупицын И. И. Проблема охраны большого баклана на Байкале в свете естественной динамики его ареала // Известия Самарского научного центра Российской академии наук. 2016. Т. 18, № 2. С. 182-185. Текст: непосредственный.

27. Пыжьянов С. В., Тупицын И. И., Сафронов Н. Н. Новое в авифауне Байкальского побережья // Русский орнитологический журнал. Экспресс-выпуск. 1997. 31. С. 16-18. Текст: непосредственный.

28. Пыжьянов С. В., Пыжьянова М. С. Современное состояние большого баклана на Байкале и Хубсугуле (Монголия) // Известия Иркутского государственного университета. Серия: Биология. Экология. 2010. Т. 2, № 1. С. 60-63. Текст: непосредственный.

29. Пыжьянова М. С. Влияние реинтродукции большого баклана на население околоводных птиц Байкала // Биоразнообразие: глобальные и региональные процессы: материалы всероссийской конференции молодых ученых с международным участие / Институт общей и экспериментальной биологии СО РАН. Улан-Удэ, 2016. С. 202-203. Текст: непосредственный.

30. Пыжьянова М. С. Трофические связи крупных колониальных рыбоядных птиц на Байкале // Русский орнитологический журнал. 2018. Т. 27. № 1685. С. 5241-5244. Текст: непосредственный.

31. Пыжьянова М. С. Трофические связи крупных колониальных рыбоядных птиц на Байкале // Современные проблемы орнитологии Сибири и Центральной Азии: материалы VI Международной орнитологической конференции / ответственный редактор В. В. Попов. 2018. С. 193-196. Текст: непосредственный. 
32. Пыжьянова М. С., Пыжьянов С. В., Ананин А. А. Большой баклан в Центральной Азии: динамика ареала в XX-XXI веках // Экосистемы Центральной Азии в современных условиях социально-экономического развития: материалы международной конференции. Т. 1. Улан-Батор (Монголия), 8-11 сентября 2015 г. Улан-Батор, 2015. С. 341-344. Текст: непосредственный.

33. Радде Г. Донесения натуралиста Сибирской экспедиции Г. Радде // Вестник РГО. Ч. 15 (VI). Санкт-Петербург, 1856. Текст: непосредственный.

34. Рябицев В. К. Птицы Урала, Приуралья и Западной Сибири: справ.-определитель. Изд. 3. Екатеринбург: Изд-во Урал. ун-та, 2008. 633 с. Текст: непосредственный.

35. Степанян Л. С. Конспект орнитологической фауны России и сопредельных территорий. Москва: Академкнига, 2003. 808 с. Текст: непосредственный.

36. Сумъяа Д., Скрябин Н. Г. Птицы Прихубсугулья. Иркутск: Изд-во ИГУ, 1989. 200 с. Текст: непосредственный.

37. Тупицын И. И., Подковыров В. А. Большой баклан на озере Хубсугул // Россия и Монголия в многополярном мире: итоги и перспективы сотрудничества на рубеже тысячелетий. Иркутск, 2000. С. 68-69. Текст: непосредственный.

38. Туров С. С. Материалы по фауне птиц Баргузинского края // Сборник трудов профессоров и преподавателей Иркутского гос. ун-та. Иркутск, 1923. Вып. 4. С. 132-169. Текст: непосредственный.

39. Фефелов И. В., Анисимов Ю. А., Безруков А. В. Большой баклан Phalacrocorax carbo - новый гнездящийся вид дельты Селенги (озеро Байкал) // Русский орнитологический журнал. 2016. Т. 25. № 1233. С. 3-6. Текст: непосредственный.

40. Шкатулова А. П. Голенастые, веслоногие и чайковые птицы Бурятской АССР // Фауна и ресурсы позвоночных бассейна оз. Байкал. Улан-Удэ: Изд-во БФ СО АН СССР, 1980. С. 144-147. Текст: непосредственный.

41. Штегман Б. К. Основы орнитогеографического деления Палеарктики. Фауна СССР. Птицы. Москва; Ленинград: Изд-во АН СССР, 1938. Т. 1, вып. 2. 157 с. Текст: непосредственный.

42. Yelayev E. Bird communities of the ecotone areas in the South of Eastern Siberia. Кишинев: LAP LAMBERT Academic Publishing, 2016. 100 p.

Статья поступила в редакцию 02.09.2021; одобрена после рецензирования 06.09.2021; принята к публикации 01.10.2021.

\section{NESTING HISTORY AND ABUNDANCE DYNAMICS \\ OF THE GREAT CORMORANT (Phalacrocorax carbo L., 1758) \\ IN BAIKAL SIBERIA}

Erdeni N. Elayev

Dr. Sci. (Biol.), Prof.,

Dorzhi Banzarov Buryat State University

24a Smolina St., Ulan-Ude 670000, Russia

elaev967@yandex.ru

Tsydypzhap Z. Dorzhiev

Dr. Sci. (Biol.), Prof.,

Dorzhi Banzarov Buryat State University

24a Smolina St., Ulan-Ude 670000, Russia

Chief Researcher,

Institute of General and Experimental Biology SB RAS,

6 Sakhyanovoy St., Ulan-Ude 670037, Russia

tsydypdor@mail.ru 
Э. Н. Елаев и др. История гнездования и динамика численности большого баклана (Phalacrocorax carbo L., 1758) в Байкальской Сибири

Aleksandr A. Ananin

Dr. Sci. (Biol.), Deputy Director for Research,

Zapovednoe Podlemorye

71 Lenina St., Ust-Barguzin 671623, Russia

Chief Researcher,

Institute of General and Experimental Biology SB RAS,

6 Sakhyanovoy St., Ulan-Ude 670047, Russia

a_ananin@mail.ru

Sergey V. Pyzhyanov

Dr. Sci. (Biol.), Prof.,

Irkutsk State University

8 Nizhnyaya Naberezhnay, Irkutsk 664011, Russia

pyzh@list.ru

Gennady A. Yankus

Researcher,

Zapovednoe Podlemorye

71 Lenina St., Ust-Barguzin 671623, Russia

jankus@rambler.ru

Evgeniya N. Badmaeva

Cand. Sci. (Biol.), A/Prof.,

Dorzhi Banzarov Buryat State University

24a Smolina St., Ulan-Ude 670000, Russia

jessi@inbox.ru

\section{Mariya S. Mokridina}

Dr. Sci. (Biol.), Senior Lecturer of Natural Sciences Department,

Irkutsk State University

8 Nizhnyaya Naberezhnay St., Irkutsk 664011, Russia

rjs-92@mail.ru

Irina A. Aurzanaeva

Master's Student of Zoology and Ecology Department,

Dorzhi Banzarov Buryat State University

24a Smolina St., Ulan-Ude 670000, Russia

Researcher,

Zapovednoe Podlemorye

71 Lenina St., Ust-Barguzin 671623, Russia

aurzanaeva@gmail.com

Abstract. The article describes the history of the stay and modern distribution of the great cormorant (Phalacrocorax carbo L., 1758) in Baikal Siberia as a result of its secondary expansion in the first quarter of the $21^{\text {st }}$ century. The main places of work were the Selenga River delta, Maloe More Strait, , Chivyrkuisky Bay Islands, Verkhne-Angarsky Sor on Lake Baikal, Upper Angara and Barguzin Basins, Lake Gusinoye in Cisbaikalia, and Transbaikalia, where according to well-known literary sources this species lived from the $17^{\text {th }}$ to the mid- $20^{\text {th }}$ centuries. We traced the dynamics of the Cormorant population in different areas based on direct accounting of birds in breeding colonies, as well as non-breeding birds. This made it possible to estimate the total number of cormorants in 2021 on Lake Baikal and 
the stabilization of their number in accordance with the ecological capacity of the environment. We also considered the area of the great cormorant with subspecies, and determined the hydrological changes of its habitats.

Keywords: the great cormorant, distribution, nesting, Baikal Siberia.

For citation

Elayev E. N., Dorzhiev Ts. Z., Ananin A. A. et al. Nesting History and Abundance Dynamics of the Great Cormorant (Phalacrocorax Carbo L., 1758) in Baikal Siberia. Bulletin of Buryat State University. Biology, Geography. 2021; 3: 21-32 (In Russ.).

The article was submitted 02.09.2021; approved after reviewing 06.09.2021; accepted for publication 01.10.2021. 